\title{
Pengaruh Dana Pihak Ketiga, Fee Based Income, Non Performing Financing, Financing to Deposit Ratio, Overhead Cost, terhadap Pembiayaan pada PT Bank Syariah Bukopin dengan Total Aset sebagai variabel Intervening
}

\author{
Ami Nullah Marlis Tanjung \\ Aminullahmarlis_sesy@yahoo.com \\ Universitas Islam Negeri Sumatera Utara
}

\begin{abstract}
This research aims to determine and analyze the relationship among Total Assets on Financing, Third Party Funds on Financing and Total Assets, Non Performing Financing on Financing and Total Assets, Fee Based Income on Total Assets, Financing of Deposit Ratio on Financing, and Overhead Costs on Financing at PT Bank Syariah Bukopin for the 2010 - June 2018 research year.The technique of data collection in this study usedtime seriessecondary dataon the quarterly published financial statements of PT Bank Syariah Bukopin. The analytical method used Descriptive Analysis and Classical Assumption Test as well as Analysis path helped by LISREL Software version 8.8. Based on the results of the research conducted on alpha 5\%, the researcher concluded that the results of calculating diagram of LISREL path analysis showed that the variables of Third Party Funds that had an effect on intervening variables were Total Asset, but Fee Based Income and Non Performing Financing took no effect on Total Assets. Then Third Community Funds and Financing of Deposit Ratio had a significant effect on Financing. However, Total Assets, Non Performing Financing, Overhead Costs had no effect on Financing at PT Bank Syariah Bukopin in the year of research.
\end{abstract}

Keywords : Third Party Funds, Non Performing Financing,Financing of Deposit Ratio, Fee Based Income, Overhead Costs, Total Assets and Financing

\begin{abstract}
Abstrak
Penelitian ini bertujuan untuk mengetahui dan menganalisis hubungan antar Total Aset terhadap Pembiayaan, Dana Pihak Ketiga terhadap Pembiayaan dan Total Aset, Non Performing Financing terhadap Pembiayaan dan Total Aset, Fee Based Income terhadap Total Aset, Financing to Deposit Ratio terhadap Pembiayaan serta Overhead Cost terhadap pembiayaan pada PT Bank Syariah Bukopin tahun penelitian 2010 - Juni 2018.Teknik pengumpulan data dalam penelitian ini menggunakan data sekunder time series pada laporan keuangan publikasi triwulan PT Bank Syariah Bukopin. Metode analisis menggunakan Analisis Deskriptif dan Uji Asumsi Klasik serta Analisis Jalur dibantu dengan Software LISREL versi 8.8.Dari hasil penelitian yang dilakukan pada alpha 5\%, penulis menyimpulkan bahwa hasil hitung diagram jalur LISREL Path Analisys menunjukkan bahwa bahwa variabel Dana Pihak Ketiga berpengaruh terhadap variabel intervening yaitu Total Aset, namun Fee Based Income dan Non Performing Financing tidak berpengaruh terhadap Total Aset. Kemudian Dana Pihak Ketiga dan Financing to Deposit Ratio berpengaruh signifikan terhadap Pembiayaan. namun Total Aset, Non Performing Financing, Overhead Cost tidak
\end{abstract}


berpengaruh terhadap Pembiayaan pada PT Bank Syariah Bukopin pada tahun penelitian.

Kata kunci : Dana Pihak Ketiga, Non Performing Financing, Financing to Deposit Ratio, Fee Based Income, Overhead Cost, Total Aset dan Pembiayaan.

\section{Pendahuluan}

Bank Syariah Bukopin merupakan bank yang termasuk kategori bank umum kategori usaha satu (BUKU I) dimana modal inti dibawah $1 \mathrm{~T}$. Bank yang memiliki aset dibawah $1 \mathrm{~T}$ bergantung kepada pembiayaan untuk menghasilkan laba usaha. sementara selama ini penelitian lain selalu membahas kepada bank dengan modal inti diatas $5 \mathrm{~T}$, yang mana Bank - bank tersebut tidak bergantung pada pembiayaan sebagai sumber pendapatan melainkan kepada transaksi derivatif seperti treasury dan lain sebagainya. maka dari hal inilah yang mendasari peneliti tertarik kepada PT Bank syariah bukopin sebagai objek penelitian dengan fokus utama adalah pembiayaan. berikut tabel bank umum syariah kategori usaha satu dengan modal dibawah $1 \mathrm{~T}$.

Tabel 1.1

Daftar Bank Umum Syariah Kategori Usaha Satu (BUKU 1)

\begin{tabular}{|c|c|c|c|c|c|c|}
\hline No & Nama bank & Aset & DPK & FDR & Pembiayaan & Ekuitas \\
\hline 1 & Bank BCA Syariah & 5.961 .356 & 4.736 .859 & $88,50 \%$ & 4.191 .001 & 996.300 \\
\hline 2 & Bank Syariah Bukopin & 7.166 .257 & 5.498 .424 & $82,44 \%$ & 4.532 .635 & 998.520 \\
\hline 3 & Bank Victoria Syariah & 2.003 .114 & 1.574 .159 & $83,59 \%$ & 1.262 .926 & 257.000 \\
\hline 4 & Bank Panin Dubai Syariah & 8.629 .275 & 7.525.232 & $80,50 \%$ & 4.495 .721 & 617.009 \\
\hline 5 & Maybank Syariah & 1.275 .648 & 274.805 & $85,94 \%$ & 485.242 & 819.307 \\
\hline
\end{tabular}

Terlihat bahwa Bank Syariah Bukopin selanjutnya disebut BSB, memiliki porsi ekuitas yang paling besar dikelasnya. peneliti sangat tertarik kepada variabel pembiayaan, selain itu BSB merupakan tempat peneliti bekerja, sehingga peneliti memilih BSB sebagai objek penelitian.

Telah banyak dilakukan penelitian terdahulu yang membahas tentang variabel pembiayaan, namun beberapa kesimpulan penelitian menghasilkan pendapat yang berseberangan satu dengan yang lainnya, seperti penelitian yang menunjukkan bahwa terdapat tidak signifikannya variabel dana pihak ketiga dengan pembiayaan. ${ }^{1}$ artinya bahwa semakin banyak dana masyarakat yang terkumpul pada suatu bank maka tidak selalu diikuti oleh penyaluran pembiayaan. ini bertentangan dengan penelitian lainnya bahwa dana pihak ketiga memiliki 
pengaruh positif terhadap pembiayaan pada bank syariah di Indonesia. ${ }^{2}$ Penelitian ini diperkuat oleh penelitian lainnya bahwa perkembangan Aset perbankan syariah di Indonesia dipengaruhi oleh dana pihak ketiga dan total pembiayaan. ${ }^{3}$

Kemudian penelitian lain menyebutkan bahwa Non Performing Financing (NPF) tidak memiliki pengaruh terhadap pembiayaan mudharabah dimana NPF yang semakin naik tidak membawa perubahan pada sisi pembiayaan, diikuti oleh penelitian di Bank Muamalat mengatakan bahwa CAR,NPF dan ROA tidak berpengaruh signifikan terhadap pembiayaan. ${ }^{4}$ Namun penelitian ini tidak sejalan dengan penelitian berikutnya yang menunjukkan bahwa dana pihak ketiga dan NPF secara simultan memiliki pengaruh terhadap pembiayaan bagi hasil. ${ }^{5}$ Semakin besar nilai NPF kepercayaan masyarakat akan semakin kecil pada bank untuk menyimpan dananya, dimana penurunan maupun kenaikan dana akan mempengaruhi penyaluran pembiayaan. ${ }^{6}$ Variabel Financing to Deposit Ratio (FDR) juga berpengaruh terhadap pembiayaan, bahwa semakin baik tingkat FDR suatu bank maka semakin baik pula rasio dana pihak ketiga. ${ }^{7}$

Dengan banyaknya berbagai kesimpulan penelitian yang tidak sesuai satu dengan berbagai penelitian yang lainnya, membuat peneliti tertarik untuk melakukan penelitian tentang beberapa variabel yang mempengaruhi pembiayaan, di mana pembiayaan merupakan salah satu sumber pendapatan bank terbesar. berikut ini tabel laporan keuangan BSB :

\section{Tabel 1 Laporan Keuangan Publikasi Tahunan PT. Bank Syariah Bukopin} (dalam jutaan Rp.)

\begin{tabular}{|c|r|r|r|r|r|r|c|}
\hline \multirow{2}{*}{ Tahun } & \multicolumn{10}{|c|}{ VARIABEL } \\
\cline { 2 - 8 } & \multicolumn{1}{|c|}{ TA } & \multicolumn{1}{c|}{ DPK } & NPF & \multicolumn{1}{c|}{ FDR } & \multicolumn{1}{c|}{ OHC } & \multicolumn{1}{c|}{ FBI } & PMB \\
\hline $\mathbf{2 0 1 0}$ & 2.193 .952 & 1.621 .913 & 3,80 & 0,99 & 33.595 & 208.802 & 1.611 .773 \\
\hline $\mathbf{2 0 1 1}$ & 2.730 .026 & 2.291 .736 & 1,74 & 0,84 & 33.595 & 143.623 & 1.917 .219 \\
\hline $\mathbf{2 0 1 2}$ & 2.716 .107 & 2.850 .782 & 4,57 & 0,99 & 27.273 & 173.266 & 2.831 .020 \\
\hline $\mathbf{2 0 1 3}$ & 4.343 .069 & 3.272 .262 & 4,27 & 1,00 & 35.251 & 153.895 & 3.281 .655 \\
\hline $\mathbf{2 0 1 4}$ & 5.160 .517 & 3.994 .957 & 4,07 & 0,81 & 42.238 & 154.819 & 3.250 .720 \\
\hline $\mathbf{2 0 1 5}$ & 5.827 .154 & 4.756 .303 & 2,99 & 0,91 & 60.816 & 178.099 & 4.307 .132 \\
\hline $\mathbf{2 0 1 6}$ & 7.019 .599 & 4.742 .609 & 3,17 & 0,91 & 96.702 & 245.095 & 4.299 .486 \\
\hline $\mathbf{2 0 1 7}$ & 7166257 & 5501424 & 4,18 & 0,82 & 795.755 & 84.766 & 4534163 \\
\hline $\mathbf{2 0 1 8}$ & 6430226 & 4686355 & 4,94 & 0,8957 & 353.022 & 158.818 & 419748 \\
\hline
\end{tabular}


Pada tahun 2011 Jumlah pembiayaan yang disalurkan naik sebesar $1.9 \mathrm{~T}$ tetapi Biaya Operasional, NPF, FDR turun masing - masing sebesar 143 M, 1.74\%, 83.66\%. kemudian di tahun 2012 terjadi kenaikan NPF disertai kenaikan PYD, DPK dan Biaya Operasional yang mengakibatkan turunnya Aset, FDR dan Fee Based perusahaan masing masing sebesar 2.7 T, 99,31\% , 27T. Selanjutnya tahun 2013 terjadi kenaikan Total Aset, DPK, Pembiayaan dan Fee Based, tetapi tidak diikuti oleh NPF dan biaya operasional yang mana ini berbanding terbalik dengan tahun sebelumnya. Kemudian di tahun 2014 Total Aset, DPK, Fee Based, dan Biaya Operasional naik tetapi tidak diikuti oleh Pembiayaan yang diberikan, NPF, FDR yang malah turun masing masing sebesar 3.2 T, 4.07\% dan 81.37\%. selanjutnya di tahun 2015 terjadi kenaikan hampir di seluruh variabel penelitian, hanya NPF yang turun sebesar 2.99\%. dan yang terakhir di tahun 2016 Total Aset, Fee Based dan Biaya Operasional naik tetapi tidak diikuti oleh variabel lain.Terakhir pada tahun 2017 semua variabel terjadi kenaikan dengan perbaikan keuangan manajemen.

Dari fenomena keuangan yang telah diuraikan di atas, tidak sesuai dan senada dengan beberapa teori dan penelitian yang dilakukan sebelumnya, di mana terdapat korelasi yang tinggi antara aset dan DPK dan aset dengan pembiayaan menunjukkan adanya hubungan linier yang kuat dab korelasi ini cenderung positif. 8 DK merupakan salah satu factor yang mempengaruhi pembiayaan, semakin besar DPK yang berhasil dihimpun oleh bank syariah, maka semakin besar pula pembiayaan yang akan disalurkannya. kenaikan NPF akan menyebabkan penyaluran dana berkurang atau sebaliknya menurunnya jumlah NPF akan menaikkan jumlah penyaluran dana bank syariah kepada masyarakat. ${ }^{9}$ Penelitian lain bahwa variabel DPK dan FDR yang berpengaruh signifikan terhadap volume pembiayaan, sedangkan NPF tidak berpengaruh signifikan terhadap volume pembiayaan. secara parsial bahwa DPK dan modal bank berpengaruh positif dan signifikan terhadap penyaluran pembiayaan, sementara suku bunga tidak mempengaruhi. ${ }^{10}$

\section{Aset}

Aktiva (asset) dapat didefinisikan sebagai sumber daya yang dikuasai oleh perusahaan sebagai akibat dari peristiwa masa lalu dari mana manfaat ekonomi di masa depan diharapkan akan diperoleh perusahaan. ${ }^{11}$ 


\section{Pengaruh Total Aset terhadap Pembiayaan}

Aset merupakan suatu indikator pertumbuhan bank yang sangat menarik untuk diteliti, perkembangan aset perbankan syari'ah Indonesia dipengaruhi oleh dana pihak ketiga (DPK) dan total pembiayaan. ${ }^{12}$ Penelitian lain membuktikan bahwa DPK dan pembiayaan merupakan dua faktor yang mempengaruhi aset secara siginifikan yang berarti bahwa pengoptimalan aset dapat dilakukan melalui peningkatan penghimpunan DPK dan mempromosikan pembiayaan kepada masyarakat. ${ }^{13}$ Disebutkan bahwa terjadi korelasi yang tinggi antara Aset, DPK dan aset dengan pembiayaan, menunjukkan bahwa ada hubungan linier yang kuat antara aset dengan DPK serta aset dengan pembiayaan. korelasi ini cenderung bernilai positif, artinya jika nilai DPK naik maka nilai aset akan naik pula, sedangkan pada pembiayaan, jika pembiayaan naik, maka nilai aset juga akan naik pula. ${ }^{14}$ Salah satu praktisi perbankan syari'ah di Medan mengatakan dengan meningkatnya suatu aset bank, maka bank tersebut harus bisa menyalurkan pembiayaan lebih besar lagi di karnakan suatu bank harus menjaga rasio antara DPK dan pembiayaan agar laba atau spread yang dihasilkan besar dan akan menguntungkan bank. ${ }^{15}$

\section{Pengertian DPK (Dana Pihak Ketiga)}

Menurut PAPSI 2013 Dana Pihak Ketiga adalah simpanan nasabah dalam bentuk tabungan, giro dan deposito yang dihimpun perbankan syari'ah pada saat tertentu.

\section{Pengaruh Dana Pihak Ketiga (DPK) terhadap Pembiayaan}

Penelitian Syukriah menyebutkan bahwa dana pihak ketiga berpengaruh secara positif dan signifikan terhadap penyaluran pembiayaan pada BPRS di Indonesia. Artinya semakin tinggi DPK maka semakin tinggi pula penyaluran pembiayaan. $^{16}$ Penelitian lain yang memiliki keterkaitan variabel dengan penelitian ini mengemukakan bahwa dana pihak ketiga adalah salah satu faktor yang berpengaruh signifikan dalam penyaluran dana bank syari'ah. ${ }^{17}$ 


\section{Pengaruh Dana Pihak Ketiga (DPK) terhadap Total Aset}

Disebutkan bahwa terjadi korelasi yang tinggi antara Aset, DPK dan aset dengan pembiayaan, menunjukkan bahwa ada hubungan linier yang kuat antara aset dengan DPK serta aset dengan pembiayaan. korelasi ini cenderung bernilai positif, artinya jika nilai DPK naik maka nilai aset akan naik pula, sedangkan pada pembiayaan, jika pembiayaan naik, maka nilai aset juga akan naik pula. ${ }^{18}$

\section{Non performing financing (NPF)}

Non Performing Loan (NPL) atau Non performing financing (NPF) adalah kredit atau pembiayaan bermasalah yang terdiri dari kredit yang berklasifikasi kurang lancar, diragukan dan macet. Pengertian lain di sebutkan Non performing financing (NPF) adalah rasio antara pembiayaan yang bermasalah dengan total pembiayaan yang disalurkan oleh bank syari'ah.

\section{Pengaruh Non Performing Financing (NPF) terhadap Pembiayaan}

Semakin besar pinjaman yang diberikan oleh bank maka semakin besar pula risiko pembiayaan yang akan dihadapi oleh bank tersebut. ${ }^{19}$ Rasio NPF merupakan yang paling penting untuk menentukan kelangsungan hidup suatu bank, NPF mencerminkan risiko pembiayaan,semakin kecil NPF semakin kecil pula risiko pembiayaan yang ditanggung pihak bank. ${ }^{20}$

\section{Pengaruh Non Performing Financing (NPF) terhadap Total Aset}

Apabila suatu bank telah kehilangan kepercayaan oleh nasabahnya, maka nasabah bisa saja menarik dananya secara besar besaran dan serentak (rush) yang menyebabkan penurunan total aset dan bank kehilangan modal dan akhirnya dapat diliquidasi oleh regulator. ${ }^{21}$ Berdasarkan penelitian dihasilkan bahwa rasio pembiayaan macet yang dikaitkan bank islam rata rata 6,29\% lebih rendah dari pada bank konvensional dengan rata rata 7,08\% menunjukkan bahwa bank bank islam cenderung memiliki kualitas aset yang lebih tinggi. Dengan demikian mereka lebih mungkin memiliki risiko kebangkrutan lebih rendah dari pada bank konvensional. ${ }^{22}$ 
Non Performing Financing $=\quad$ Total Pembiayaan Bermasalah

Total Pembiayaan

\section{Fee Based Income (FBI)}

Fee based income (pendapatan non magin atau bagihasil) adalah pendapatan provisi, fee atau komisi yang diterima bank dari pemasaran produk maupun transaksi jasa perbankan yang dibebankan kepada nasabah sehubungan dengan produk dan jasa bank yang dinikmatinya. Dalam PSAK No.31 Bab I huruf A angka 03 dijelaskan bahwa dalam operasinya bank melakukan penanaman dalam aktiva produktif deperti pembiayaan dan surat-surat berharga juga diberikan memberikan komitmen dan jasa-jasa lain yang digolongkan sebagai "fee based operation", atau "off balance sheet activities".

\section{Pengaruh Fee based income terhadap Total Aset}

Penelitian yang terdahulu menyebutkan bahwa semakin tinggi pendapatan non operasional suatu bank berpengaruh terhadap meningkatnya suatu aset bank. ${ }^{23}$

\section{Financing to Deposite Ratio (FDR)}

Financing to deposit ratio adalah Rasio yang digunakan untuk mengukur komposisi jumlah pembiayaan yang diberikan dibandingkan dengan jumlah dana masyarakat dan modal sendiri yang digunakan. ${ }^{24}$

\section{Pengaruh FDR terhadap pembiayaan}

Semakin tinggi FDR pada suatu bank akan mengakibatkan semakin rendahnya liquiditas bank tersebut karena jumlah dana yang diperlukan untuk membiayai pembiayaan menjadi semakin besar, sebaliknya semakin rendah FDR akan mengakibatkan semakin tingginya liquiditas bank yang bersangkutan. Hal ini menunjukkan pengaruh pada kemampuan pembiayaan pada suatu bank, karena semakin tinggi FDR maka kemampuan pembiayaan yang disalurkan oleh bank juga semakin tinggi dalam membayar kemampuan jangka pendeknya. ${ }^{25}$

Financing to Deposite Ratio

$(\mathrm{FDR})=$

Pembiayaan yang diberikan Dana Masyarakat 


\section{Overhead Cost (OHC)}

Overhead cost adalah biaya - biaya yang dikeluarkan oleh suatu bank untuk dapat melakukan kegiatan operasionalnya yaitu funding dan financing untuk menghasilkan keuntungan, di mana overheadcost ini menjadi pengurang laba suatu bank. Dalam pengertian lain Overhead cost adalah seluruh biaya (di luar biaya dana) yang dikeluarkan oleh bank dalam menjalankan kegiatannya.

\section{Pengaruh Overhead Cost (OHC) terhadap Pembiayaan}

Bank yang inefisiensi dan tidak sehat secara individual dapat melemahkan sistem keungan melalui margin pembiayaan yang tinggi. ${ }^{26}$ Jadi secara parsial tingginya tingkat inefisiensi suatu bank, dapat mempengaruhi kenaikkan tingkat margin dan bagi hasil dan secara langsung mempengaruhi total pembiayaan suatu bank karna tinggi rendahnya margin atau bagihasil suatu bank dapat mempengaruhi keputusan nasabah. dalam penelitian lain menyebutkan bahwa semakin tinggi biaya pendidikan maka akan berpengaruh di sisi aktiva bank yang diperoleh BUS dan UUS di Indonesia. ${ }^{27}$

\section{Pembiayaan}

Pembiayaan merupakan salah satu tugas pokok bank, yaitu pemberian fasilitas penyediaan dana untuk memenuhi kebutuhan pihak pihak yang merupakan defisit unit. Tujuan pembiayaan berdasarkan prinsip syari'ah untuk meningkatkan kesempatan kerja dan kesejahteraan ekonomi sesuai dengan nilai nilai islam. Pembiayaan tersebut harus dapat dinikmati oleh sebanyak banyaknya pengusaha yang bergerak dibidang industri, peranian, dan perdagangan untuk menunjang produksi dan distribusi barang dan jasa dalam rangka memenuhi kebutahan dalam negeri maupun ekspor. ${ }^{28}$

\section{Metode Penelitian}

Pendekatan yang dilakukan dalam penelitian ini menggunakan pendekatan asosiatif / hubungan yaitu penelitian yang bertujuan untuk mengetahui hubungan antar variabel bebas dengan variabel terikat, apakah hubungan secara simetris (datangnya bersama - sama), Hubungan Kausal (sebab - akibat) atau resipokal (timbal - balik) dan nantinya akan membentuk fungsi dari variabel tersebut yang diginakan untuk menjelaskan, meramalkan dan mengontrol sesuatu. 
Jenis penelitian ini merupakan penelitian kuantitatif yang menekankan pada pengujian kepada teori - teori atau hipotesis - hipotesis melalui pengukuran variabel - variabel penelitian dalam angka (quantitative) dan melakukan analisis data dengan prosedur statis dan pemodelan sistematis.

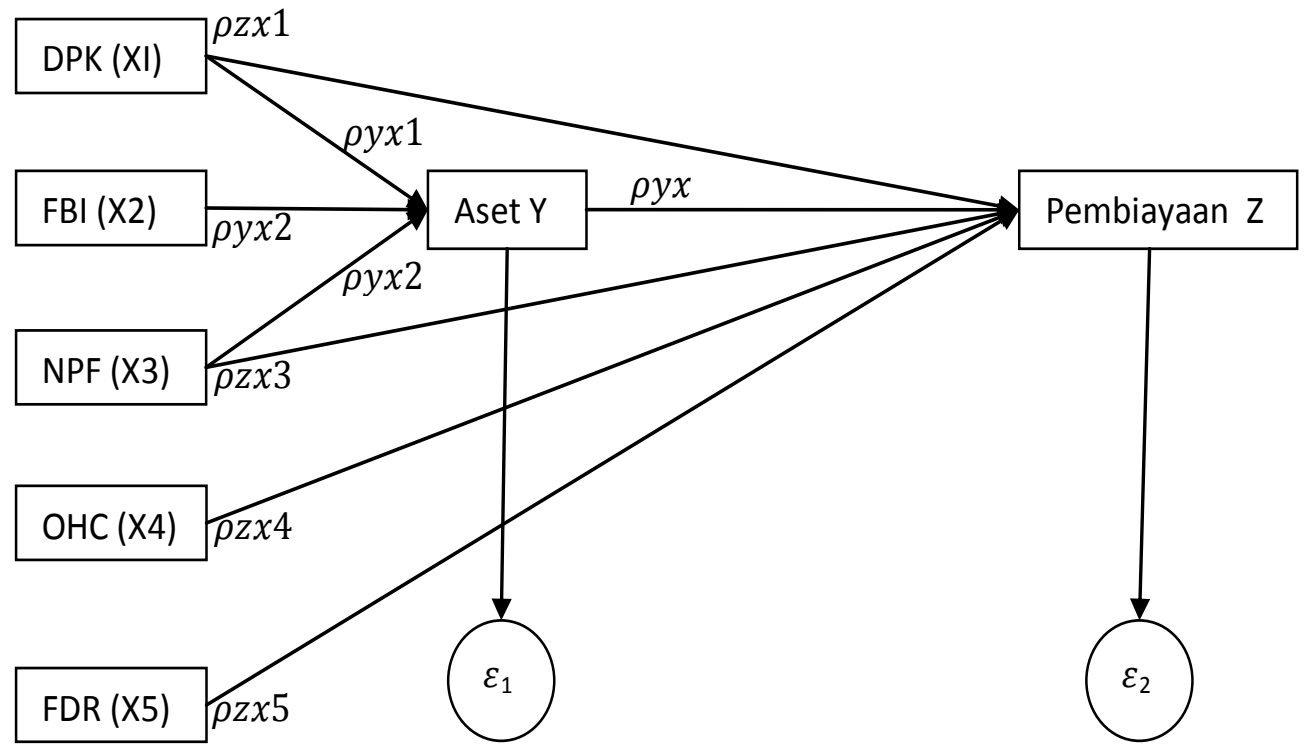

\section{Gambar 1 Kerangka Pemikiran Penelitian}

\section{Hasil Penelitian}

Pada penelitian ini, penulis menggunakan data sekunder yang diperoleh dari situs www.banksyariahbukopin.co.id dan situs www.ojk.go.id. Data diambil langsung dari laporan keuangan triwulan yang tersedia di situsnya, data diambil mulai tahun 2010 sampai dengan tahun 2018 kuartal II yaitu bulan Juni. Data yang diperoleh kemudian diolah menggunakan program LISREL 8.8 versi Student.

Berikut ini laporan keuangan triwulan PT Bank Syariah Bukopin : 
Tabel 2 Laporan Keuangan Bank Syariah Bukopin per triwulan tahun 2010-2018 (dalam jutaan Rp.)

\begin{tabular}{|c|c|c|c|c|c|c|c|c|}
\hline \multirow{2}{*}{ Tahun } & \multirow{2}{*}{ Kuartal } & \multicolumn{7}{|c|}{ VARIABEL } \\
\hline & & TA & DPK & NPF & FDR & $\mathrm{OHC}$ & FBI & PMB \\
\hline \multirow{4}{*}{2010} & Maret & 1.876 .397 & 1.380 .599 & 4,14 & 0,93 & 45.454 & 7.263 & 1.283 .292 \\
\hline & Juni & 1.944 .686 & 1.311 .950 & 3,670 & 1,09 & 94.285 & 14.750 & 1.434 .179 \\
\hline & Sept & 2.163 .300 & 1.514 .139 & 3,910 & 1,03 & 145.778 & 19.591 & 1.563 .872 \\
\hline & Des & 2.193 .952 & 1.621 .913 & 3,80 & 0,99 & 33.595 & 208.802 & 1.611 .773 \\
\hline \multirow{4}{*}{2011} & Maret & 2.089 .776 & 1.573 .254 & 0,980 & 0,95 & 53.190 & 5.987 & 1.498 .933 \\
\hline & Juni & 2.231 .126 & 1.735 .571 & 1,610 & 0,94 & 105.503 & 11.888 & 1.625 .971 \\
\hline & Sept & 2.413 .317 & 1.975 .349 & 1,570 & 0,81 & 159.519 & 15.621 & 1.606 .037 \\
\hline & Des & 2.730 .026 & 2.291 .736 & 1,74 & 0,84 & 33.595 & 143.623 & 1.917 .219 \\
\hline \multirow{4}{*}{2012} & Maret & 2.685 .143 & 2.240 .403 & 2,85 & 0,90 & 63.634 & 11.825 & 2.025 .085 \\
\hline & Juni & 3.180 .719 & 2.476 .161 & 2,50 & 0,93 & 125.584 & 17.946 & 2.313 .734 \\
\hline & Sept & 3.488 .783 & 2.609 .488 & 4,46 & 0,99 & 192.015 & 23.293 & 2.587 .334 \\
\hline & Des & 2.716 .107 & 2.850 .782 & 4,57 & 0,99 & 27.273 & 173.266 & 2.831 .020 \\
\hline \multirow{4}{*}{2013} & Maret & 3.647 .737 & 3.079 .920 & 4,28 & 0,88 & 72.605 & 4.705 & 2.700 .235 \\
\hline & Juni & 3.911 .263 & 3.204 .602 & 4,03 & 0,92 & 151.805 & 11.174 & 2.944 .480 \\
\hline & Sept & 4.124 .584 & 3.352 .211 & 3,86 & 0,94 & 242.159 & 21.330 & 3.162 .741 \\
\hline & Des & 4.343 .069 & 3.272 .262 & 4,27 & 1,00 & 35.251 & 153.895 & 3.281 .655 \\
\hline \multirow{4}{*}{2014} & Maret & 4.526 .076 & 3.428 .774 & 3,97 & 0,97 & 108.801 & 6.618 & 3.336 .389 \\
\hline & Juni & 4.645 .407 & 3.372 .243 & 2,67 & 1,03 & 224.998 & 20.970 & 3.473 .828 \\
\hline & Sept & 4.790 .155 & 3.449 .246 & 3,81 & 1,04 & 348.221 & 28.364 & 3.580 .819 \\
\hline & Des & 5.160 .517 & 3.994 .957 & 4,07 & 0,81 & 42.238 & 154.819 & 3.250 .720 \\
\hline \multirow{4}{*}{2015} & Maret & 5.102 .475 & 3.915 .293 & 3,95 & 0,96 & 158.940 & 6.625 & 3.757 .505 \\
\hline & Juni & 5.215 .803 & 4.061 .048 & 2,63 & 0,95 & 320.158 & 17.076 & 3.857 .884 \\
\hline & Sept & 5.313 .580 & 4.336 .818 & 2,45 & 0,93 & 480.706 & 31.776 & 4.028 .106 \\
\hline & Des & 5.827 .154 & 4.756 .303 & 2,99 & 0,91 & 60.816 & 178.099 & 4.307 .132 \\
\hline \multirow{4}{*}{2016} & Maret & 6.144 .201 & 4.977 .566 & 2,34 & 0,93 & 177.536 & 16.256 & 4.626 .563 \\
\hline & Juni & 6.487 .998 & 5.199 .152 & 2,37 & 0,93 & 363.611 & 32.171 & 4.813 .672 \\
\hline & Sept & 6.675 .144 & 5.427 .808 & 2,05 & 0,88 & 550.362 & 48.769 & 4.788 .765 \\
\hline & Des & 7.019 .599 & 4.742 .609 & 3,17 & 0,91 & 96.702 & 245.095 & 4.299 .486 \\
\hline \multirow{4}{*}{2017} & Maret & 6401365 & 5354150 & 1,69 & 0,92 & 200.674 & 26895 & 4907915 \\
\hline & Juni & 6990618 & 5634192 & 2,25 & 0,89 & 402.986 & 55.685 & 5024021 \\
\hline & Sept & 7579230 & 5746537 & 3,1 & 1,48 & 609.317 & 69.684 & 8476168 \\
\hline & Des & 7166257 & 5501424 & 4,18 & 0,82 & 795.755 & 84.766 & 4534163 \\
\hline \multirow{2}{*}{2018} & Maret & 6860068 & 5188251 & 3,86 & 0,8295 & 169.909 & 10.004 & 4303743 \\
\hline & Juni & 6430226 & 4686355 & 4,94 & 0,8957 & 353.022 & 158.818 & 4197484 \\
\hline
\end{tabular}

\section{Uji Validitas dan Reliabilitas}

Uji validitas bertujuan untuk mengukur valid atau tidaknya suatu item pernyataan, valid tidaknya item pernyataan bisa dilihat dari membandingkan nilai r-hitung dengan r-tabel, data dikatakan valid jika r-hitung lebih besar dari r-tabel $\left(\mathrm{r}_{\text {-hitung }}>\mathrm{r}_{\text {tabel }}\right) .{ }^{29}$ Sedangkan Uji Reliabilitas dilakukan untuk melihat sejauh mana hasil pengukuran dapat dipercaya. Dengan dilakukan pengukuran terhadap suatu objek yang sama diperoleh hasil yang relative sama artinya mempunyai konsistensi pengukuran yang baik. Nilai reliabilitas bisa dilihat dari Cronbach Alpa $>0.70$. 


\section{Tabel 3 Uji Realibilitas}

\section{Reliability Statistics}

\begin{tabular}{|r|r|}
\hline $\begin{array}{c}\text { Cronbach's } \\
\text { Alpha }\end{array}$ & N of Items \\
\hline, 778 & 7 \\
\hline
\end{tabular}

Tabel 4 Uji Validitas

\begin{tabular}{|l|r|r|r|r|}
\hline \multicolumn{1}{||}{ Item-Total Statistics } \\
& $\begin{array}{c}\text { Scale Mean if } \\
\text { Item Deleted }\end{array}$ & $\begin{array}{c}\text { Scale } \\
\text { Variance if } \\
\text { Item Deleted }\end{array}$ & $\begin{array}{c}\text { Corrected } \\
\text { Item-Total } \\
\text { Correlation }\end{array}$ & $\begin{array}{c}\text { Cronbach's } \\
\text { Alpha if Item } \\
\text { Deleted }\end{array}$ \\
\hline Total Aset & 7153984,263 & $8,908 \mathrm{E}+12$ &, 969 &, 626 \\
Dana Pihak Ketiga & 8150058,763 & $1,148 \mathrm{E}+13$ &, 975 &, 614 \\
Non Performing & 11685214,57 & $2,284 \mathrm{E}+13$ &,- 011 &, 800 \\
Financing & 11685216,82 & $2,284 \mathrm{E}+13$ &, 138 &, 800 \\
Financing to Deposit & 11477982,56 & $2,165 \mathrm{E}+13$ &, 667 &, 780 \\
Ratio & 11625159,00 & $2,273 \mathrm{E}+13$ &, 151 &, 799 \\
Overhead Cost & 8333690,616 & $1,136 \mathrm{E}+13$ &, 924 &, 630 \\
Feebased Income & & & & \\
Pembiayaan & &
\end{tabular}

Hasil di atas menunjukkan bahwa nilai Cronbach's Alpha yang dihasilkan oleh output SPSS.16 for windows adalah sebesar 0,778 artinya semua variabel reliabel karena nilai Cronbach's Alpha yang dihasilkan lebih besar dari 0.7 (0.778 > 0.7). dengan demikian variabel variabel dalam penelitian ini adalah valid.

\section{Uji Normalitas.}

Uji normalitas bertujuan untuk mengetahui normal atau tidaknya suatu distribusi data. Pada dasarnya uji normalitas membandingkan antara data yang dimiliki dengan berdistribusi normal yang dimiliki mean dan standar deviasi yang sama dengan data kita.

Tabel 5 Uji Normalitas

\begin{tabular}{|l|r|r|r|r|r|r}
\hline \multirow{4}{*}{} & \multicolumn{2}{|c|}{ Kests of Normality } \\
\cline { 2 - 7 } & Statistic & df & Sig. & Statistic & df & \multicolumn{1}{c}{ Sig. } \\
\hline TA &, 133 & 33 &, 200 &, 930 & 33 &, 034 \\
DPK &, 111 & 33 &, $200^{*}$ &, 937 & 33 &, 057 \\
NPF &, 136 & 33 &, 124 &, 945 & 33 &, 095 \\
FDR &, 146 & 33 &, 072 &, 815 & 33 &, 000 \\
OHC &, 117 & 33 &, $200^{*}$ &, 931 & 33 &, 038 \\
FBI &, 133 & 33 &, 145 &, 932 & 33 &, 039 \\
PMB &, 099 & 33 &, $200^{*}$ &, 905 & 33 &, 007 \\
\hline
\end{tabular}

*. This is a lower bound of the true significance.

a. Lilliefors Significance Correction 
Suatu data dikatakan berdistribusi normal apabila nilai Sig. pada Kolmogorov-Smirnov ${ }^{a}$ lebih besar dari 0,05 (Sig.> 0,05). ${ }^{30}$ Dilihat dari data diatas, semua hasil sig $(>0,05)$. Sehingga dapat disimpulkan bahwa data dalam penelitian ini berdistribusi normal. Dengan demikian data yang diuji telah berdistribusi normal serta bisa dianggap mewakili popolasi yang merupakan syarat untuk dilakukannya parametric test.

\section{Uji Homoskedastisitas}

Homoskedastisitas adalah variance variabel dependent yang bisa menerangkan hubungan dependent tidak terkonsentrasi hanya pada limited range variabel dependent pada masing-masing nilai variabel independent, dengan kata lain, sebaran (variance) nilai variabel dependent harus relative sama dengan masing-masing nilai variabel predictor. ${ }^{31}$

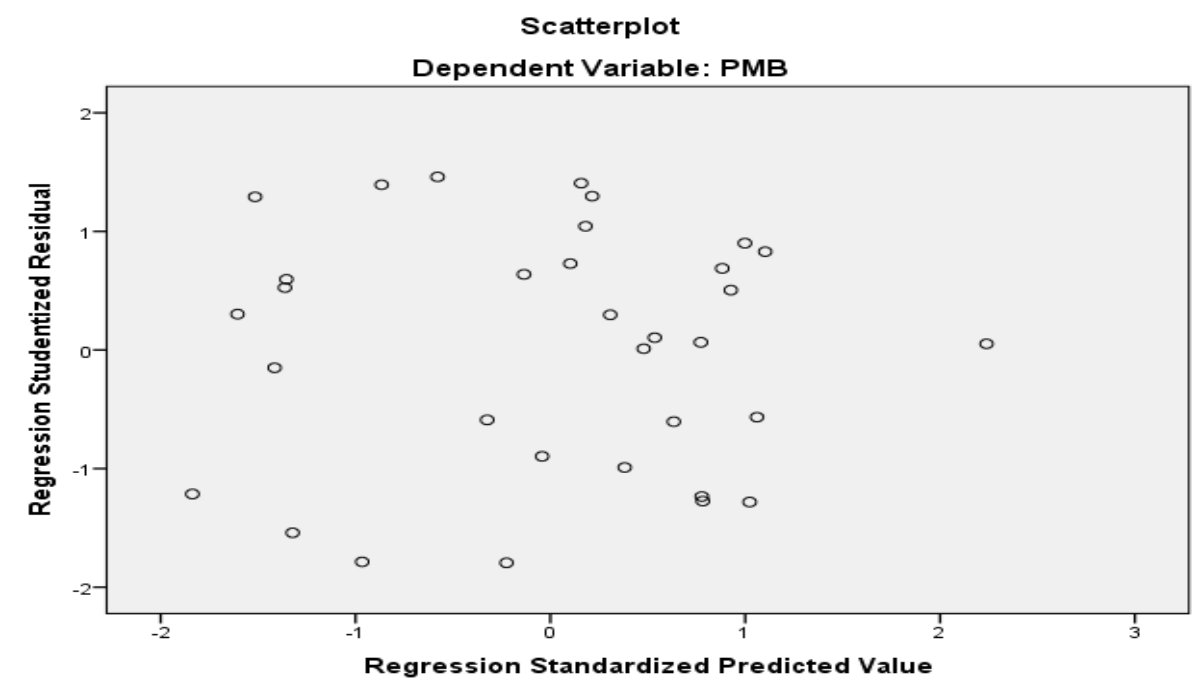

\section{Gambar 2 Scatterplot Uji Heteroskedastisitas}

Dari gambar di atas menunjukkan bahwa sebaran data residual tidak membentuk pola tertentu dan menyebar di bawah dan diatas angka nol pada sumbu Y, dengan demikian model terbebas dari gejala heteroskedastisitas.

\section{Uji Multikolonilieritas}

Multikolonieritas adalah korelasi yang sangat tinggi atau sangat rendah yang terjadi pada hubungan diantara variabel bebas. Multikolonieritas dapat 
dilihat dari nilai VIF (variance-inflating factor) jika nilai VIF $<10$, tingkat kolonieritas dapat ditoleransi. Adapun hasil uji multikolonieritas sebagai berikut :

\section{Tabel 6 Uji Multikolinearitas}

\begin{tabular}{|c|c|c|c|c|c|c|c|c|}
\hline \multicolumn{9}{|c|}{ Coefficients $^{a}$} \\
\hline \multirow{2}{*}{\multicolumn{2}{|c|}{ Model }} & \multicolumn{2}{|c|}{ Unstandardized Coefficients } & \multirow{2}{*}{$\begin{array}{c}\text { Standardized } \\
\text { Coefficients } \\
\text { Beta }\end{array}$} & \multirow[b]{2}{*}{$t$} & \multirow[b]{2}{*}{ Sig. } & \multicolumn{2}{|c|}{ Collinearity Statistics } \\
\hline & & $\mathrm{B}$ & Std. Error & & & & Tolerance & VIF \\
\hline \multirow[t]{6}{*}{1} & (Constant) & 91035,044 & 386050,149 & & 236 & 815 & & \\
\hline & DPK &, 985 &, 041 & ,932 & 23,751 &, 000 & 462 & 2,166 \\
\hline & NPF & 186946,552 & 151643,256 &, 034 & 1,233 &, 228 & ,929 & 1,076 \\
\hline & FDR & 11822794,23 & 895292,698 &, 370 & 13,206 &, 000 & ,903 & 1,107 \\
\hline & $\mathrm{OHC}$ & $-59,498$ & 305,455 &,- 008 &,- 195 & 847 & 478 & 2,092 \\
\hline & FBI & 17394,057 & 87016,941 &, 006 &, 200 & .843 & 827 & 1,209 \\
\hline
\end{tabular}

Dari hasil tersebut dapat dijelaskan bahwa nilai VIF (variance-inflating factor) untuk semua variabel DPK, NPF, FDR, OHC, FBI terhadap variabel Pembiayaan lebih kecil dari 10, artinya data tersebut terbebas dari multikolonieritas.

\section{Uji Linieritas}

Uji linieritas bertujuan untuk mengetahui apakah data bersifat linier atau mengikuti garis linier atau tidak. Uji linieritas dapat diketahui melalui nilai sig. pada Deviation from Linierity. Jika nilai Sig. pada Deviation from Linierity $>0,05$ maka hubungan antar variabel tersebut bersifat linier. ${ }^{32}$

Tabel 7 Uji Linieritas Pembiayaan-Total Aset

\begin{tabular}{|c|c|c|c|c|c|c|c|}
\hline & & & $\begin{array}{l}\text { Sum of } \\
\text { Squares }\end{array}$ & df & Mean Square & $\mathrm{F}$ & Sig. \\
\hline \multirow[t]{5}{*}{ Pembiayaan *Total Aset } & \multirow[t]{3}{*}{ Between Groups } & (Combined) & $7,269 \mathrm{E}+13$ & 32 & $2,272 E+12$ & 5,441 & 329 \\
\hline & & Linearity & $6,142 E+13$ & 1 & $6,142 E+13$ & 147,109 &, 052 \\
\hline & & Deviation from Linearity & $1,127 E+13$ & 31 & $3,637 E+11$ & .871 &, 708 \\
\hline & \multicolumn{2}{|l|}{ Within Groups } & $4,175 E+11$ & 1 & $4,175 E+11$ & & \\
\hline & \multicolumn{2}{|l|}{ Total } & $7,311 \mathrm{E}+13$ & 33 & & & \\
\hline
\end{tabular}

Dari hasil output SPSS tersebut dapat disimpulkan bahwa nilai Sig. pada Deviation from Linierity yakni Total Aset $(\mathrm{TA}) *$ Pembiayaan $(\mathrm{PMB})=0,708$ lebih besar dari 0,05, maka dapat disimpulkan bahwa data tersebut bersifat linier. 
Tabel 8 Uji Linieritas Pembiayaan-Dana Pihak Ketiga

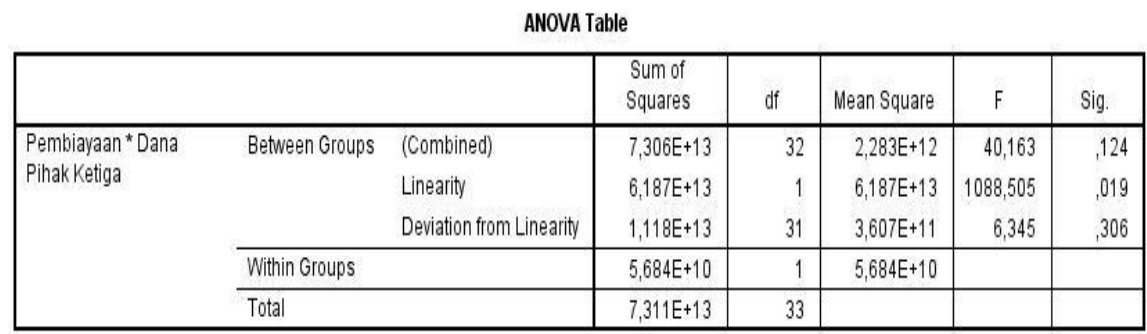

Dari hasil output SPSS tersebut dapat disimpulkan bahwa nilai Sig. pada Deviation from Linierity yakni Dana Pihak Ketiga (DPK)*Pembiayaan (PMB) $=$ 0,306 lebih besar dari 0,05, maka dapat disimpulkan bahwa data tersebut bersifat linier.

Tabel 9 Uji Linieritas Total Aset-Dana Pihak Ketiga

\begin{tabular}{|c|c|c|c|c|c|c|c|}
\hline \multicolumn{8}{|c|}{ ANOVA Table } \\
\hline & & & $\begin{array}{l}\text { Sum of } \\
\text { Squares }\end{array}$ & df & Mean Square & $\mathrm{F}$ & Sig. \\
\hline \multirow{5}{*}{$\begin{array}{l}\text { Total Aset* Dana Pihak } \\
\text { Ketiga }\end{array}$} & \multirow[t]{3}{*}{ Between Groups } & (Combined) & $1,103 E+14$ & 32 & $3,447 E+12$ & 36,978 &, 130 \\
\hline & & Linearity & $1,071 E+14$ & 1 & $1,071 E+14$ & 1148,333 & .019 \\
\hline & & Deviation from Linearity & $3,259 \mathrm{E}+12$ & 31 & $1,051 \mathrm{E}+11$ & 1,128 &, 646 \\
\hline & Within Groups & & $9,323 E+10$ & 1 & $9,323 E+10$ & & \\
\hline & Total & & $1,104 E+14$ & 33 & & & \\
\hline
\end{tabular}

Dari hasil output SPSS tersebut dapat disimpulkan bahwa nilai Sig. pada Deviation from Linierity yakni Dana Pihak Ketiga (DPK) *Total Aset $(\mathrm{TA})=$ 0,646 lebih besar dari 0,05, maka dapat disimpulkan bahwa data tersebut bersifat linier.

Tabel 10 Uji Linieritas Total Aset-Fee Based Income

\begin{tabular}{|c|c|c|c|c|c|c|c|}
\hline \multicolumn{8}{|c|}{ ANOVA Table } \\
\hline & & & $\begin{array}{l}\text { Sum of } \\
\text { Squares }\end{array}$ & df & Mean Square & $\mathrm{F}$ & Sig. \\
\hline \multirow{5}{*}{$\begin{array}{l}\text { Total Aset * Feebased } \\
\text { Income }\end{array}$} & \multirow[t]{3}{*}{ Between Groups } & (Combined) & $1,097 E+14$ & 32 & $3,428 \mathrm{E}+12$ & 4,832 &, 348 \\
\hline & & Linearity & $3,687 E+12$ & 1 & $3,687 \mathrm{E}+12$ & 5,197 & 263 \\
\hline & & Deviation from Linearity & $1,060 E+14$ & 31 & $3,420 E+12$ & 4,820 &, 348 \\
\hline & \multicolumn{2}{|l|}{ Within Groups } & $7,095 \mathrm{E}+11$ & 1 & $7,095 \mathrm{E}+11$ & & \\
\hline & \multicolumn{2}{|l|}{ Total } & $1,104 E+14$ & 33 & & & \\
\hline
\end{tabular}

Dari hasil output SPSS tersebut dapat disimpulkan bahwa nilai Sig. pada Deviation from Linierity yakni Feebased Income (FBI) *Total Aset (TA) = 0,348 lebih besar dari 0,05, maka dapat disimpulkan bahwa data tersebut bersifat linier. 


\section{Tabel 11 Uji Linieritas Total PMB-NPF}

\begin{tabular}{|c|c|c|c|c|c|c|c|}
\hline \multicolumn{8}{|c|}{ ANOVA Table } \\
\hline & & & $\begin{array}{c}\text { Sum of } \\
\text { Squares }\end{array}$ & df & Mean Square & $\mathrm{F}$ & Sig. \\
\hline \multirow[t]{5}{*}{$P M B * N P F$} & Between Groups & (Combined) & 6,795 & 31 &, 219 & 4,620 &, 355 \\
\hline & & Linearity &, 028 & 1 &, 028 &, 589 &, 583 \\
\hline & & Deviation from Linearity & 6,767 & 30 &, 226 & 4,754 &, 350 \\
\hline & Within Groups & & .047 & 1 & 047 & & \\
\hline & Total & & 6,842 & 32 & & & \\
\hline
\end{tabular}

Dari hasil output SPSS tersebut dapat disimpulkan bahwa nilai Sig. pada Deviation from Linierity yakni Non Performing Financing (NPF) *Pembiayaan $(\mathrm{PMB})=0,350$ lebih besar dari 0,05, maka dapat disimpulkan bahwa data tersebut bersifat linier.

Tabel 12 Uji Linieritas Total Aset-NPF

\begin{tabular}{|c|c|c|c|c|c|c|c|}
\hline \multicolumn{8}{|c|}{ ANOVA Table } \\
\hline & & & $\begin{array}{l}\text { Sum of } \\
\text { Squares }\end{array}$ & df & Mean Square & $\mathrm{F}$ & Sig. \\
\hline \multirow[t]{5}{*}{ TA*NPF } & Between Groups & (Combined) & 6,304 & 31 & .203 & 1,571 & .569 \\
\hline & & Linearity & .064 & 1 & .064 & .497 & 609 \\
\hline & & Deviation from Linearity & 6,240 & 30 & 208 & 1,607 & .564 \\
\hline & Within Groups & & 129 & 1 & ,129 & & \\
\hline & Total & & 6,433 & 32 & & & \\
\hline
\end{tabular}

Dari hasil output SPSS tersebut dapat disimpulkan bahwa nilai Sig. pada Deviation from Linierity yakni Non Performing Financing (NPF) *Total Aset $(\mathrm{TA})=0,564$ lebih besar dari 0,05, maka dapat disimpulkan bahwa data tersebut bersifat linier.

Tabel 13 Uji Linieritas Total PMB-FDR

\begin{tabular}{|c|c|c|c|c|c|c|c|}
\hline \multicolumn{8}{|c|}{ ANOVA Table } \\
\hline & & & $\begin{array}{l}\text { Sum of } \\
\text { Squares }\end{array}$ & df & Mean Square & $\mathrm{F}$ & Sig. \\
\hline \multirow[t]{5}{*}{$P M B * F D R$} & Between Groups & (Combined) & 3,951 & 20 & 198 &, 857 & .633 \\
\hline & & Linearity & .156 & 1 &, 156 &, 677 & .426 \\
\hline & & Deviation from Linearity & 3,795 & 19 & 200 & 866 & .622 \\
\hline & Within Groups & & 2,998 & 13 & .231 & & \\
\hline & Total & & 6,949 & 33 & & & \\
\hline
\end{tabular}

Dari hasil output SPSS tersebut dapat disimpulkan bahwa nilai Sig. pada Deviation from Linierity yakni Financing to Deposit Ratio (FDR) *Pembiayaan $(\mathrm{PMB})=0,622$ lebih besar dari 0,05, maka dapat disimpulkan bahwa data tersebut bersifat linier. 
Tabel 14 Uji Linieritas Total Aset-Dana Pihak Ketiga

\begin{tabular}{|c|c|c|c|c|c|c|c|}
\hline & & & $\begin{array}{l}\text { Sum of } \\
\text { Squares }\end{array}$ & df & Mean Square & $\mathrm{F}$ & sig. \\
\hline \multirow[t]{5}{*}{$\mathrm{PMB}^{*} \mathrm{OHC}$} & \multirow[t]{3}{*}{ Between Groups } & (Combined) & 6,934 & 32 & .217 & 14,390 & 206 \\
\hline & & Linearity & 2,659 & 1 & 2,659 & 176,572 &, 048 \\
\hline & & Deviation from Linearity & 4,275 & 31 &, 138 & 9,159 &, 257 \\
\hline & \multicolumn{2}{|l|}{ Within Groups } & 015 & 1 &, 015 & & \\
\hline & \multicolumn{2}{|l|}{ Total } & 6,949 & 33 & & & \\
\hline
\end{tabular}

Dari hasil output SPSS tersebut dapat disimpulkan bahwa nilai Sig. pada Deviation from Linierity yakni Overhead Cost $(\mathrm{OHC}) *$ Pembiayaan $(\mathrm{PMB})=$ 0,257 lebih besar dari 0,05, maka dapat disimpulkan bahwa data tersebut bersifat linier.

\section{Uji Autokorelasi}

Uji autokorelasi bertujuan untuk menguji apakah dalam model regresi linier ada korelasi antara kesalahan pengganggu (disturbance term) pada periode (t-1). Masalah Autokorelasi sering terjadi pada date time series, sementara pada data cross section sangat jarang terjadi sehingga uji autokorelasi tidak wajib dilakukan pada penelitian yang menggunakan data cross section.

\section{Tabel 15 Uji Autokorelasi}

\begin{tabular}{|ll|r|r|r|r|r|}
\hline & & & \multicolumn{1}{|c|}{ Model Summary $^{\mathbf{b}}$} \\
FBI_2 & Model & \multicolumn{1}{|c|}{ R } & R Square & \multicolumn{1}{c|}{$\begin{array}{c}\text { Adjusted R } \\
\text { Square }\end{array}$} & $\begin{array}{c}\text { Std. Error of the } \\
\text { Estimate }\end{array}$ & Durbin-Watson \\
\hline 1,00 & 1 &, $990^{\mathrm{a}}$ &, 981 &, 977 & 229513,73671 & 1,994 \\
\hline
\end{tabular}

a. Predictors: (Constant), FBI, OHC, FDR, NPF, DPK, TA

b. Dependent Variable: PMB

Dari data di atas dapat diambil kesimpulan bahwa, DW berada diantara dU dan 4-dU, yaitu $1.8913<1,994<2,1087$, artinya tidak terjadi autokorelasi.

\section{Analisis Jalur}

Aplikasi analisis jalur dalam penelitian ini menggunakan program LISREL 8.80 (Student). Output yang dihasilkan dalam penelitian ini adalah sebagai berikut 


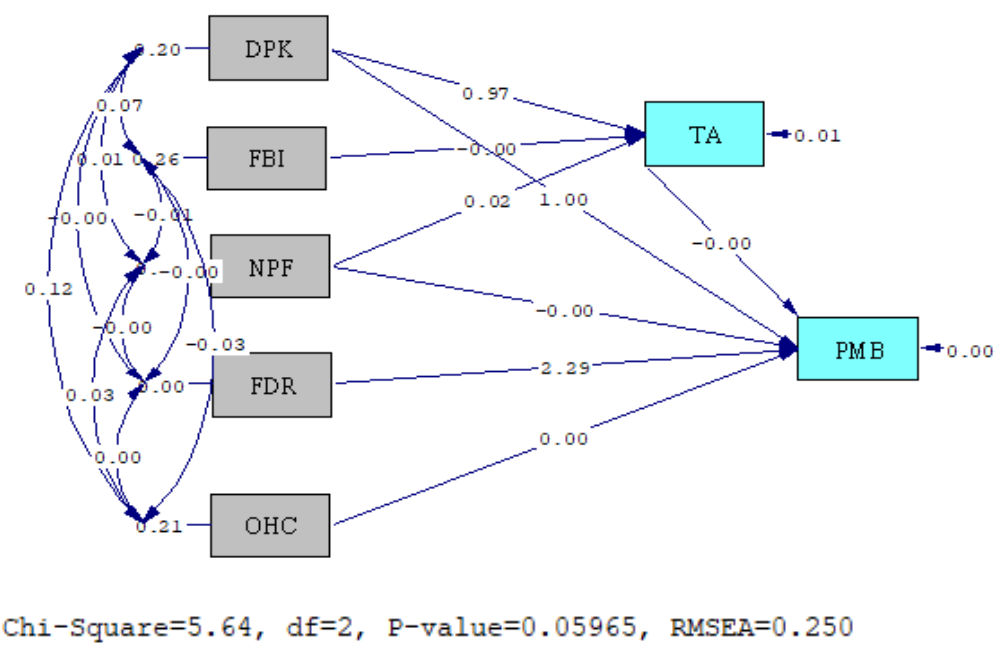

\section{Gambar 3 Diagram Jalur (Model Estimates)}

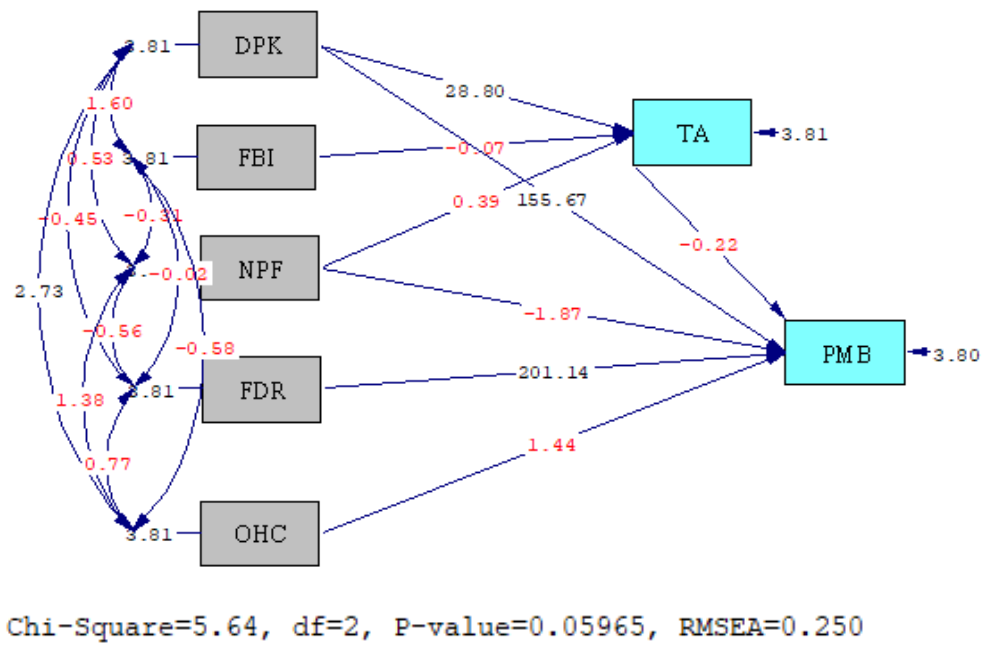

\section{Gambar 4 Diagram Jalur (t-value)}

\section{Pembahasan Penelitian}

Paradigma penelitian ini dibangun atas lima hipotesis penelitian. Untuk menguji hipotesis tersebut dapat dihitung dari nilai t-hitung. Kemudian nilai thitung tersebut dibandingkan dengan nilai t-tabel. Apabila t-hitung $>$ t-tabel maka hipotesis diterima. 


\section{Pengaruh Total Aset dengan Pembiayaan}

Hipotesis pertama $\left(\mathrm{H}_{1}\right)$ adalah : Total Aset tidak berpengaruh terhadap pembiayaan pada PT. Bank Syari'ah Bukopin. Berdasarkan hasil analisis data didapat bahwa koefisien jalur hubungan antara TA dan PMB sebesar -0,00 dengan nilai t-hitung yang dihasilkan adalah sebesar -0,33. Nilai ini lebih kecil dari nilai $\mathrm{t}$-tabel sebesar 2,05. Oleh karenanya hipotesis yang diajukan dalam penelitian ini dapat ditolak $\left(\mathrm{H}_{0}\right.$ ditolak). Hasil ini tidak sejalan dengan hasil penelitian yang menyebutkan bahwa Aset merupakan suatu indikator pertumbuhan bank yang sangat menarik untuk diteliti, perkembangan aset perbankan syari'ah Indonesia dipengaruhi oleh dana pihak ketiga (DPK) dan total pembiayaan. ${ }^{33}$ Dimana dapat dijelaskan bahwa total aset yang meningkat dari tahun ke tahun seiring dengan tumbuhnya suatu bank tidak selamanya diikuti oleh pembiayaan yang disalurkan juga ikut naik, terlihat dari hasil analisis diatas bahwa ada faktor - faktor lain yang memiliki pengaruh yang kuat dan linier terhadap pembiayaan pada PT Bank Syariah Bukopin dari tahun 2010 s/d Juni 2018.

\section{Pengaruh Dana Pihak Ketiga (DPK) terhadap Pembiayaan}

Hipotesis Kedua $\left(\mathrm{H}_{2}\right)$ adalah: Dana Pihak Ketiga berpengaruh terhadap Pembiayaan pada PT. Bank Syariah Bukopin. Berdasarkan hasil analisis data didapat bahwa koefisien jalur hubungan antara Dana Pihak Ketiga (DPK) dan Pembiayaan (PMB) sebesar 1,00 dengan nilai t-hitung yang dihasilkan adalah sebesar 156,68. Nilai ini lebih besar dari nilai t-tabel sebesar 2,05. Oleh karenanya hipotesis yang diajukan dalam penelitian ini dapat diterima $\left(\mathrm{H}_{2}\right.$ diterima). Hasil ini sejalan dengan hasil penelitian yang menyebutkan bahwa dana pihak ketiga berpengaruh secara positif dan signifikan terhadap penyaluran pembiayaan pada BPRS di Indonesia. Artinya semakin tinggi DPK maka semakin tinggi pula penyaluran pembiayaan. ${ }^{34}$ Dapat dideskripsikan bahwa antara tahun $2010 \mathrm{~s} / \mathrm{d}$ 2018 PT Bank Syariah Bukopin memiliki Dana Pihak Ketiga yang meningkat dari tahun ketahun juga diikuti oleh kenaikan pembiayaan, dikarnakan semakin banyak Dana Pihak Ketiga yang berhasil dihimpun oleh suatu bank maka harus segera disalurkan melalui pembiayaan untuk menghasilkan keuntungan serta dapat membayar bagihasil atas Dana Pihak Ketiga tersebut, apabila tidak maka akan banyak dana yang mengendap di kas (Idle Fund) yang akan merugikan bank karna. 


\section{Pengaruh Dana Pihak Ketiga (DPK) terhadap Total Aset}

Hipotesis ketiga $\left(\mathrm{H}_{3}\right)$ adalah: Dana Pihak Ketiga (DPK) berpengaruh terhadap Total Aset (TA) pada PT Bank Syariah Bukopin. Berdasarkan hasil analisis data didapat bahwa koefisien jalur hubungan antara Dana Pihak Ketiga (DPK) dan Total Aset (TA) sebesar 0,97 dengan nilai t-hitung yang dihasilkan adalah sebesar 28,8. Nilai ini lebih besar dari nilai t-tabel sebesar 2,05. Oleh karenanya hipotesis yang diajukan dalam penelitian ini dapat diterima ( $\mathrm{H}_{3}$ diterima). Ini sejalan dan seirama dengan penelitian yang menyebutkan bahwa terjadi korelasi yang tinggi antara Aset, DPK dan aset dengan pembiayaan, menunjukkan bahwa ada hubungan linier yang kuat antara aset dengan DPK serta aset dengan pembiayaan. korelasi ini cenderung bernilai positif, artinya jika nilai DPK naik maka nilai aset akan naik pula, sedangkan pada pembiayaan, jika pembiayaan naik, maka nilai aset juga akan naik pula. ${ }^{35}$ Dapat dideskripsikan bahwa meningkatnya Dana Pihak Ketiga pada PT Bank Syariah Bukopin dari tahun 2010 s/d 2018 juga diikuti oleh Total Aset (TA), dikarnakan Dana Pihak Ketiga yang berhasil dihimpun disalurkan melalui pembiayaan dan bentuk lainnya yang menghasilkan aset bagi bank itu sendiri. Tingginya Dana Pihak Ketiga yang ada di Bank Syariah Bukopin maka bank akan mengubah dana pihak ketiga tersebut kedalam bentuk aset atau pembiayaan sehingga total aset pada tahun peneltian meningkat.

\section{Pengaruh Fee Based Income terhadap Total Aset}

Hipotesis kelima $\left(\mathrm{H}_{4}\right)$ adalah : Fee Based Income berpengaruh terhadap Total Aset pada PT Bank Syariah Bukopin. Berdasarkan hasil analisis data didapat bahwa koefisien jalur hubungan antara Fee Based Income dan Total Aset sebesar -0,00 dengan nilai t-hitung yang dihasilkan adalah sebesar -0,07. Nilai ini lebih besar dari nilai t-tabel sebesar 2,05. Oleh karenanya hipotesis yang diajukan dalam penelitian ini dapat ditolak ( $\mathrm{H}_{5}$ ditolak). Penelitian ini sejalan dengan penelitian yang menyebutkan bahwa fee based income ini tidak berpengaruh terhadap pembiayaan dikarnakan pembiayaan merupakan proses rangkaian memberikan pinjaman atau bentuk lainnya di mana memiliki waktu jatuh tempo yang panjang, sedangkan fee based income tidak memerlukan waktu yang panjang seperti pembiayaan. Dan penelitian ini berseberangan dengan penelitian yang menyebutkan bahwa semakin 
tinggi pendapatan non operasional suatu bank berpengaruh terhadap meningkatnya suatu aset bank. ${ }^{36}$

\section{Pengaruh Non Performing Financing (NPF) terhadap pembiayaan}

Hipotesis keenam $\left(\mathrm{H}_{5}\right)$ adalah : Non Performing Financing (NPF) tidak berpengaruh terhadap pembiayaan pada PT. Bank Syariah Bukopin. Berdasarkan hasil analisis data didapat bahwa koefisien jalur hubungan antara Non Performing Financing (NPF) dan pembiayaan sebesar -0,00 dengan nilai t-hitung yang dihasilkan adalah sebesar-1,93. Nilai ini lebih kecil dari nilai t-tabel sebesar 2,05. Oleh karenanya hipotesis yang diajukan dalam penelitian ini dapat ditolak $\left(\mathrm{H}_{6}\right.$ ditolak). Penelitian ini sejalan dengan penelitian yang menyebutkan bahwa dana pihak ketiga berpengaruh signifikan terhadap volume pembiayaan bagi hasil, dan non performing financing tidak berpengaruh signifikan terhadap volume pembiayaan bagi hasil. ${ }^{37}$ Dapat dideskripsikan bahwa semakin meningkatnya atau menurunnya Non Performing Financing (NPF) tidak mempunyai pengaruh terhadap pembiayaan pada PT Bank Syariah Bukopin, dikarnakan apabila terjadi NPF yang Relatif tinggi, maka stakeholder akan segera membantu untuk menambah modal sehingga tidak berdampak kepada pembiayaan yang disalurkan.

\section{Pengaruh Non Performing Financing (NPF) terhadap Total Aset}

Hipotesis keenam $\left(\mathrm{H}_{6}\right)$ adalah : Non Performing Financing (NPF) tidak berpengaruh terhadap Total Aset pada PT. Bank Syariah Bukopin. Berdasarkan hasil analisis data didapat bahwa koefisien jalur hubungan antara Non Performing Financing (NPF) dan Total Aset sebesar 0,02 dengan nilai t-hitung yang dihasilkan adalah sebesar 0,40. Nilai ini lebih kecil dari nilai t-tabel sebesar 2,05. Oleh karenanya hipotesis yang diajukan dalam penelitian ini dapat ditolak $\left(\mathrm{H}_{5}\right.$ ditolak). Penelitian ini sejalan dengan penilitian yang menyebutkan bahwa Non Performing Financing (NPF) tidak memiliki pengaruh terhadap pembiayaan mudharabah dimana NPF yang semakin naik tidak membawa perubahan pada sisi pembiayaan, diikuti oleh penelitian di Bank Muamalat mengatakan bahwa CAR,NPF dan ROA tidak berpengaruh signifikan terhadap pembiayaan. ${ }^{38}$ Dapat dideskripsikan bahwa NPF yang cenderung naik pada tahun penelitian tidak berpengaruh dan tidak mempengaruhi total aset pada PT Bank Syariah Bukopin, kenaikan NPF yang relatif tidak terlalu tinggi menyebabkan perseroan masih 
mampu dalam mengelola dan memitigasi dampak yang ditimbulkan akibat risiko NPF tersebut sehingga tidak menggerus total aset yang dimiliki oleh perseroan.

\section{Pengaruh Financing to Deposit Ratio (FDR) terhadap Pembiayaan}

Hipotesis ketujuh $\left(\mathrm{H}_{7}\right)$ adalah : Financing to Deposit Ratio (FDR) berpengaruh terhadap Pembiayaan pada PT. Bank Syariah Bukopin. Berdasarkan hasil analisis data didapat bahwa koefisien jalur hubungan antara Financing to Deposit Ratio (FDR) dan Pembiayaan sebesar 2.28 dengan nilai t-hitung yang dihasilkan adalah sebesar 202,26. Nilai ini lebih besar dari nilai t-tabel sebesar 2,05 . Oleh karenanya hipotesis yang diajukan dalam penelitian ini dapat diterima $\left(\mathrm{H}_{8}\right.$ diterima). Ini sejalan dengan penelitian yang menyebutkan bahwa Loan to Deposit Ratio (LDR) atau Financing to Deposit Ratio (FDR) secara parsial berpengaruh positif dan signifikan terhadap aset. ${ }^{39}$ Dapat dideskripsikan bahwa Financing to deposit ratio pada tahun penelitian memiliki pengaruh terhadap pembiayaan.

\section{Pengaruh Overhead Cost (OHC) terhadap Pembiayaan}

Hipotesis kedelapan $\left(\mathrm{H}_{8}\right)$ adalah : Overhead Cost (OHC) tidak berpengaruh terhadap Pembiayaan pada PT. Bank Syariah Bukopin. Berdasarkan hasil analisis data didapat bahwa koefisien jalur hubungan antara Overhead Cost (OHC) dan Pembiayaan sebesar 0,00 dengan nilai t-hitung yang dihasilkan adalah sebesar 1,75. Nilai ini lebih kecil dari nilai t-tabel sebesar 2,05. Oleh karenanya hipotesis yang diajukan dalam penelitian ini ditolak $\left(\mathrm{H}_{8}\right.$ ditolak). Penelitian ini berbeda dengan peneltian yang menyebutkan bahwa bank yang inefisiensi dan tidak sehat secara individual dapat melemahkan sistem keuangan melalui margin pembiayaan yang tinggi. ${ }^{40}$ Dapat dideskripsikan bahwa semakin besar biaya yang harus dikeluarkan bank untuk menghasilkan keuntungan maka, tidak berdampak pada keputusan penyaluran pembiayaan pada PT Bank Syariah Bukopin. Ini dikarenakan perseroan mengambil spread keuntungan dari kegiatan operasional tidak terlalu besar sehingga tidak berpengaruh terhadap margin atau bagi hasil pembiayaan. Kemudian apabila biaya yang overheadcost terlalu besar maka perseroan dapat menurunkan bagihasil dana simpanan nasabah sehingga tidak juga tidak berdampak kepada naiknya margin dan bagihasil pembiayaan. 


\section{Kesimpulan}

Berdasarkan hasil analisis data didapat Total Aset (TA) tidak berpengaruh terhadap Pembiayaan (PMB) pada PT. Bank Syari'ah Bukopin. Untuk Dana Pihak Ketiga (DPK) berpengaruh positif terhadap Pembiayaan (PMB) Bank Syariah Bukopin. Variabel Fee Based Income (FBI) berpengaruh negatif terhadap Total Aset (TA). Non Performing Financing (NPF) berpengaruh negatif terhadap Pembiayaan (PMB). Non Performing Financing (NPF) berpengaruh negatif terhadap Total Aset (TA). Variabel Financing to Deposit Ratio (FDR) berpengaruh positif terhadap Pembiayaan (PMB).

Berdasarkan temuan penelitian, peneliti menyarankan untuk bank lebih meningkatkan operasionalnya serta penggunaan dananya. Dan juga untuk bank akan lebih baik lagi bila pihak manajer lebih memperhatikan dalam pengelolaan operasionalnya (khususnya aktiva lancar ataupun aktiva tetap seimbang dengan penjualan yang menguntungkan agar kinerja perusahaan pada periode tahun yang akan datang menunjukkan peningkatan lagi. Dan juga sebaiknya perusahaan senantiasa melakukan analisis rasio-rasio keuangan secara periodik demi mengetahui sejauh mana kinerja perusahaan yang telah dilakukan serta sebagai pertimbangan manajemen dalam mengambil kebijakan pada tahun-tahun berikutnya.

\section{Catatan}

${ }^{1}$ Ustad Fattah Alhakim,'Pengaruh tingkat perkembangan dana pihak ketiga terhadap pemberian pembiayaan pada BMT di Magelang" (Thesis Keuangan dan perbankan syariah).h. 81

${ }^{2}$ Rina Destiana,"Analisis dana pihak ketiga dan risiko terhadap pembiayaan musyarakah dan mudharabah pada bank syariah di Indonesia". Dalam Jurnal Vol.XVII,No.02. h. 42.

${ }^{3}$ Faridah Yuliani,rer pol Heri Kuswanto,"Peramalan aset dengan memperhatikan dana pihak ketiga (DPK) dan pembiayaan perbankan syari'ah di Indonesia dengan metode fungsi transfer". Dalam Jurnal .h.1.

${ }^{4}$ Wuri Arianti Novi."Analisis pengaruh DPK,CAR,NPF, dan ROA terhadap pembiayaan dan profitabilitas pada bank syariah". (Tesis Fak Ekonomi.UNDIP 2010), h.1.

${ }_{5}^{5}$ Pengaruh dana pihak ketiga, non performing financing, return on aset, capital adequacy ratio, terhadap pembiayaan bagi hasil, pada bank umum syariah di Indonesia periode 2010-2013. Dalam Jurnal Manajemen, Vol. 02 2015. H.1.

${ }^{6}$ Silva Tri Putrisatya,Analisis pengaruh Dana Pihak Ketiga (DPK), Return on assets (ROA), dan Non performing financing (NPF) terhadap pembiayaan Musyarakah dan Mudharabah". (Thesis Fak, Ekonomi.Univ.UMY.2016),h.1.

Slamet Riyadi,"Pengaruh pembiayaan bagihasil , pembiayaan jual beli, Financing to Deposit Ratio, dan non performing Financing terhadap profitabilitas bank Umum syari'ah di Indonesia”. Dalam Accounting Analysis Journal.h. 469.

${ }^{8}$ Faridah Yuliani,rer pol Heri Kuswanto,"Peramalan aset dengan memperhatikan dana pihak ketiga (DPK) dan pembiayaan perbankan syari'ah di Indonesia dengan metode fungsi transfer". Dalam Jurnal.h.1.

${ }^{9}$ Septiana Ambarwati, "Faktor - faktor yang mempengaruhi pembiayaan di bank syariah di indonesia".(Thesis, program pasca sarjana. Universitas Indonesia. Th.2008). h.20.

${ }^{10}$ Syukriah Selvie, et. al.," pengaruh dana pihak ketiga, suku bunga kredit, dan modal bank terhadap penyaluran kredit pada bank perkreditan rakyat konvensional di Indonesia". Dalam Jurnal Megister Akuntansi,pascasarjana UNSYIAH Kuala.ISSN : 2302-0164),h.55.

${ }^{11}$ Jopie Jusuf, Analisis Kredit untuk account officer, (Jakarta : Kompas Gramedia, Mei 2010),h.7.

${ }^{12}$ Faridah Yuliani,rer pol Heri Kuswanto,"Peramalan aset dengan memperhatikan dana pihak ketiga (DPK) dan pembiayaan perbankan syari'ah di Indonesia dengan metode fungsi transfer". Dalam Jurnal .h.1.

${ }_{13}^{13} \mathrm{Ibid}$,.

${ }^{14} \mathrm{Ibid}$. 

Mei 2018

${ }^{15}$ Mhd. Bakrie, Pimpinan Cabang PT. Bank Syari'ahBukopin Cab, Medan, Wawancara di Medan, Tanggal 25

${ }^{16}$ Syukriah Selvie, et. al.," pengaruh dana pihak ketiga, suku bunga kredit, dan modal bank terhadap penyaluran kredit pada bank perkreditan rakyat konvensional di Indonesia". Dalam jurnal Megister Akuntansi,pascasarjana UNSYIAH Kuala.ISSN : 2302-0164.h.55.

${ }^{17}$ Dita Andreany,"Analisis pengaruh Dana Pihak Ketiga, Tingkat bagi hasil, dan Non Performing Financing terhadap volume pembiayaan berbasis bagi hasil pada perbankan syari'ah di Indonesia,"dalam Simposium Nasional Akuntansi XIV Aceh 2011. h.9

${ }^{18} \mathrm{Ibid}$,.

${ }^{19}$ I Dewa Agung Nanditya Putra,"pengaruh pinjaman yang diberikan terhadap nilai perusahaan dengan non performing loan sebagai variabel pemoderasi”. Dalam E-jurnal Akuntansi univ.Udayana.ISSN : 2302-8556.2018.h.1206.

${ }^{20} \mathrm{Ibid}$,

${ }^{21}$ Dayong Zhang,"Non Performing loans, moral hazard, and regulation of the chinese commercial banking system" Dalam journal of banking and finance.vol.63.februari 2016.h.4.

${ }^{22}$ Sunil K Mohanty,"Banking efficiencyin gulf cooperation council $(G C C)$ countries : a comparative study".journal economics.vol.31.November 2016.h.19.

${ }^{23}$ Wahyu Dwi Priatmoko,"Pengaruh pendapatan bunga kredit dan pendapatan non bunga (fee based income) terhadap kinerja keuangan (Return on assets)". (Tesis Fakultas Ekonomi. Universitas Brawijaya.Malang 2014).h.1

${ }^{24}$ Ningsukma Hakiim,"Pengaruh internal Adequency Ratio, Financing to deposit ratio dan biaya operasional perpendapatan operasional dalam peningkatan profitabilitas industri bank syari'ah di Indonesia". Dalam Jurnal perbankan syari'ah, Vol.1.h.68.

${ }^{25}$ Amalia Yuianadkk, et, al,."Pengaruh LDR, CAR, ROA dan NPL terhadap penyaluran kredit pada bank umum di Indonesia". Dalam Jurnal Dinamika Manajemen.Vol.2.September 2014.h.171.

${ }^{26}$ Alfin Apriyana."Faktor faktor yang mempengaruhi efisiensi biaya perbankan dikawasan Asean”. Dalam Jurnal manajemen Teknologi.Vol.14.no.03.

${ }^{27}$ Ridwansyah,"Analisis pengaruh biaya pendidikan terhadap peningkatan aset dan laba pada perbankan syari'ah di Indonesia". Dalam Jurnal ekonomi.vol.XXII, NO.03.November 2017.h.334.

${ }^{28}$ Agung Faizal,"Analisis pengaruh Total Aset, dana pihak ketiga dan non performing financing (NPF) terhadap volume pembiayaan bagi hasil". (Thesis jurusan manajemen Univ.Bengkulu).h.40.

${ }^{29}$ Trianto Budi, Riset Modelling, (Pekanbaru : Adhuha Institute, Juli 2016), h.113

${ }^{30}$ Ibid., h. 120

${ }^{31}$ Hair,dkk, Multivariate Data Analysis, Sixth Edition, (Prentice Hall : Pearson Education International, 2006),

h. 120

${ }^{32}$ Trianto Budi, Riset Modelling, (Pekanbaru : Adhuha Institute, Juli 2016), h.123

${ }^{33}$ Faridah Yuliani,rer pol Heri Kuswanto,"Peramalan aset dengan memperhatikan dana pihak ketiga (DPK) dan pembiayaan perbankan syari'ah di Indonesia dengan metode fungsi transfer". Dalam Jurnal .h.1.

${ }^{34}$ Syukriah Selvie, et. al.," pengaruh dana pihak ketiga, suku bunga kredit, dan modal bank terhadap penyaluran kredit pada bank perkreditan rakyat konvensional di Indonesia". Dalam jurnal Megister Akuntansi,pascasarjana UNSYIAH Kuala.ISSN : 2302-0164.h.55

${ }^{35} \mathrm{Ibid}$,.

${ }^{36}$ Wahyu Dwi Priatmoko,"Pengaruh pendapatan bunga kredit dan pendapatan non bunga (fee based income) terhadap kinerja keuangan (Return on assets)". (Tesis Fakultas Ekonomi. Universitas Brawijaya.Malang 2014).h.1

${ }^{37}$ Isnaini ,"Analisis pengaruh dana pihak ketiga, tingkat bagi hasil, non performing financing dan modal sendiri terhadap volume pembiayaan berbasis bagihasil pada perbankan syari'ah di Indonesia".(Thesis Fak.Ekonomi.Univ.UMY).h.3.

${ }^{38}$ Wuri Arianti Novi.”Analisis pengaruh DPK,CAR,NPF,dan ROA terhadap pembiayaan dan profitabilitas pada bank syariah". (Tesis Fak Ekonomi.UNDIP 2010), h.1.

${ }^{39}$ Putu Desi Miadalyni, et, al,."Pengaruh Loan to Deposit Ratio, Loan to Asset Ratio, Capital Adequacy Ratio dan kualitas aktiva produktif terhadap profitabilitas pada PT. Bank Pembangunan daerh Bali”. (Thesis Udayana.2011) H.1545.

${ }^{40}$ Alfin Apriyana."Faktor faktor yang mempengaruhi efisiensi biaya perbankan dikawasan Asean". Dalam Jurnal manajemen Teknologi.Vol.14.no.03.

\section{Daftar Pustaka}

Al - Qur'an, Al - Baqarah, (Jakarta : Maghfirah Pustaka,2006).

AAOIFI, Accounting and Auditing Standards For Islamic Financial Institutions 1419H-1998, Manama: AAOIFI, 1998

A.George Assaf,"Technical efficiency in Saudy banks".Volume.38.Issue.5.May

11. 
Amalia, Euis. Teori Mikroekonomi, suatu perbandingan Ekonomi Islam dan Ekonomi Konvensional, Jakarta : Kencana Prenada media Group, 2010.

Dayong Zhang,"Non performing loans,moral hazard and regulation of the chinese commercial banking system”.volume.63. February 2016.

El-Ashker, Ahmed dan Rodney Wilson, Islamic Economic, USA : Danvers, 2006

El-Diwani ,Tarek, The problem with Interest, Jakarta : Akbar Media Eka Sarana. 2003

Fauziyah Adzimatinur, Sri Hartoyo dan Ranti Wiliasih,"Factors affecting the amount of financing Islamic Banking in Indonesia". Jurnal Al-Muzara'ah ISSN Departemen Ilmu Ekonomi Fakultas Ekonomi dan Manajemen, Institut Pertanian Bogor, 2016, Hal : 106

Harahap, Darwis." Determinan Dana Pihak Ketiga Bank Syariah di Indonesia : Model Vector Autoregresive “. Jurnal Iqtishadia. Vol.10.Nomor.1.2017.

Hasan,"Analisis Industri Perbankan Syariah di Indonesia ". jurnal dinamika ekonomi pembangunan, Volume.1.Nomor.1. Juli 2011.

IAI, BI, Pedoman Akuntansi Perbankan Syariah (PAPSI), Jakarta Biro Perbankan Syariah Bank Indonesia, 2013.

Ikatan Bankir Indonesia, Tata Kelola Manajemen Risiko Perbankan, Jakarta : PT Gramedia Pustaka Utama, 2014

International Sharia research Academy for Islamic Finance (ISRA), Sistem Keuangan Islam, Jakarta : PT Raja Grafindo Persada, 2015

Ifham Sholihin ,Ahmad, Buku Pintar Ekonomi Syariah, Jakarta : PT Gramedia Pustaka Utama, 2010.

Izzat Alsmadi."Building an islamic financial information system based on policy managements”.Volume.27.Issue.4.oktober 2015.

J.Econ."Prohibition of riba and gharar : a signaling and screening explanation”. Volume 103.july 2014.

Ning Zhu,"Productivity, efficiency, and non performing loansin the chinese banking industry”. Volume 52. issue 4.Desember 2015.

Siregar,Saparuddin,Akuntansi Syariah : meletakkan nilai-nilai syariah Islam dalam ilmu akuntansi. Medan : Madenatera, 2016. 
,Akuntansi : Zakat dan Infak/Sedekah sesuai PSAK 109 untuk BAZNAS dan LAZ. Medan : Wal Ashri Publishing, 2013.

Akuntansi perbankan syariah sesuai PAPSI 2013. Medan : Febi UINSU Press, 2015.

Manajemen Risiko pembiayaan pada Bank Syariah : Suatu tinjauan filsafati. Jurnal Al-ulum Volume 17nomor 1 juni 2017. 